Z. Klin. Chem. Klin. Biochem.

12. Jg. 1974 , S. $370-373$

\title{
Studies on the Methodical and Biological Variation of Proteins Quantitated by Single Radial Immunodiffusion ${ }^{1}$ )
}

\author{
By P. Spath, S. Platzer and F. Gabl with technical assistance of Edith Nachbaur
}

\author{
From the Medizinische Universitätsklinik (Head: Prof. Dr. H. Braunsteiner) Innsbruck, Austria
}

(Eingegangen am 2. Januar/4. März 1974)

For the evaluation of repeated protein quantitations, knowledge of day to day variation of levels is necessary. This study reports the day to day variation of total protein, albumin, IgG, IgA and IgM in 20 patients with chronic hepatitis, the single proteins being quantitated by a single radial immunodiffusion method. From 3 consecutive day samples drawn from a single patient the quantitations of serum values were performed on the same plate in order to reduce the intrinsic error in the methods. This error was found previously to be $2.0-4.4 \%$ for different proteins when measured on one plate. In this study the range of variation over 3 consecutive days amounted to $\pm 10-20 \%$ of the mean, being about twice the intrinsic methodical error. The total protein variation was $\pm 3.9 \%$. There being a lack of correlation between the corresponding total protein levels and those of the single fractions, a change in protein concentration during storage of the samples can be excluded as a cause of the increased variation. The existence of other factors such as biological changes is discussed. It is concluded that this day to day variation of up to $\pm 20 \%$ has to be taken into account for evaluation of protein quantitations in patients. The important role of careful sampling and storage procedures is stressed.

Für die Beurteilung von wiederholten Proteinmessungen stellt die Kenntnis der Streuung der Werte von Tag zu Tag eine wichtige Voraussetzung dar. Über solche Änderungen der Werte von Gesamteiweiß, Albumin, IgG, IgA und IgM bei 20 Patienten mit chronischer Hepatitis wird berichtet. Die einzelnen Eiweißfraktionen wurden mit der einfachen radialen Immundiffusionsmethode bestimmt. Die einem Patienten entsprechenden, von 3 aufeinanderfolgenden Tagen stammenden Serumproben wurden auf derselben Immundiffusionsplatte angesetzt, um den methodischen Fehler zu reduzieren. Auf Grund früherer Untersuchungen betrug dieser auf einer Platte 2,0-4,4 \% für verschiedene Proteine. Bei dieser Untersuchung machte die Streubreite der Dreifachwerte bis zu $\pm 10-20 \%$ des Mittelwertes und somit etwa das Doppelte der methodischen Fehlerbreite aus. Die Streuung der Gesamteiweißbestimmung betrug \pm 3,9\%. Da keine Korrelationen zwischen den Werten des Gesamteiweiß und denen der entsprechenden Eiweißfraktionen festgestellt werden konnten, erscheinen Änderungen der Eiweißkonzentrationen während der Probenaufbewahrung als Urssache für die erhöhte Streubreite ausgeschlossen. Das Vorhandensein von anderen Faktoren, 'wie etwa biologischen Einflüssen, wird diskutiert. Es wird geschlossen, daß die Streuung der Werte von Tag zu Tag bis zu $\pm 20 \%$ bei der Beurteilung von Eiweißbestimmungen mit der radialen Immundiffusion berücksichtigt werden muß. Auf die wichtige Rolle der sorgfältigen Durchfuhrung der Probenabnahme und -aufbewahrung wird hingewiesen.

The single radial immunodiffusion method of Mancini et al. (1) has found increasing use in the clinical laboratory in recent years. The availability of commercial immunodiffusion plates and the apparent technical simplicity has also resulted in the introduction of this method to laboratories with no special experience in immunological methods. Despite the fact that the first descriptions of the method by Mancini et al. (1) and Fahey and McKelvey (2) have already characterized very well the factors responsible for the methodical accuracy, not all these important factors can be followed when using commercial products. For the evaluation of results it is important that hte clinician is aware of the reliability of values obtained by a certain method. As a continuation of our previous studies on the intrinsic methodical error of the single radial immunodiffusion $(3,4)$, further factors which influence the variation of results under clinical circumstances were studied - stimulated by the question : does a specific treatment show any signi-

1) Presented in part at the 8 th International Congress on Clinical Chemistry, Copenhagen, Denmark, June 18 th-23rd, 1972. Abstract published in Scand. J. Clin. Invest. 29, Suppl. 126, 1.7 (1972). ficant effect on the concentration of different serum proteins quantitated by single radial immunodiffusion? For this purpose it was necessary to determine the reliability of a single measurement per se by performing quantiations on samples obtained separately on consecutive days from the same individual. From the results it was possible to estimate the variation of a single determination in order to establish the limits of confidence for the significant differentiation of values.

\section{Material and Methods}

\section{Patients}

20 patients suffering from chronic hepatitis were used in the investigation. On 3 consecutive days, blood was drawn from all patients before an immunosuppressive therapy and from 7 of these patients also after therapy. The conditions under which the blood was taken were identical on each occasion (fasting for 12 hours, horizontal position, short application of tourniquet for venipuncture) and the apparent clinical state of the patients remained unchanged during the 3 days. After clotting at room temperature the serum was separated and stored in carefully sealed plastic tubes at $-25^{\circ} \mathrm{C}$ for up to several months until.quantitations of the proteins were performed. Of the 27 "triple" values, corresponding to 81 single 
samples, albumin, IgG, IgA and IgM were quantitated by single radial immunodiffusion and a total of 324 protein determinations was performed.

\section{Reagents}

For the protein quantitations, commercially available Partigen immunodiffusion plates of different batches and standard sera of Behringwerke (Marburg-Lahn, W. Germany) were used.

\section{Instruments}

For the application of the samples, a Hamilton microliter syringe was used and the measurements of the precipitation rings were performed using a calibrated lens of Bausch and Lomb.

\section{Experimental procedure}

All determinations were performed by one experienced technician on different days on plates of different batches. On each plate 3 standard dilutions were applied and the following dilutions of the standard serum were used: albumin: $1: 50$ to $1: 150$, IgG: $1: 10$ to $1: 50, \operatorname{IgA}: 1: 2$ to $1: 10$, IgM: $1: 1$ (undiluted) to $1: 6$. The serum samples were diluted for the quantitation of albumin $1: 100$, of IgG $1: 40$, of IgA $1: 8$, and of IgM $1: 5$. When the precipitation ring of the serum sample was not within the range of the standard curve, the quantitation was repeated by diluting the sample adequately. Simultaneously a quality control (aliquoted samples of pooled sera from normal persons) was determined 19 times for albumin, IgG and IgM, and 18 times for IgA. On these plates 12 circularly arranged wells (Nos. 1-12) are available. The method of application of the samples is evident from table 1 . The "triple" samples from 3 consecutive days were applied in duplicate in opposite wells (Nos. 1 and 7,2 and 8 etc.) of the same plate. The 3 standard dilutions were also applied in duplicate except for the plates with the precision control. On those plates the lowest and second standard dilution were single values, and the third standard dilutions were duplicates. The plates were allowed to incubate at room temperature under humid conditions for at least 3 days until the diffusion came to an endpoint, then the means of 2 diameters from each precipitation ring were squared and plotted against the concentrations of the standard dilutions in order to obtain the standard curve. The unknown serum sample values were read in the same way and calculated from the standard curve. Total protein determinations using the biuret method (5) were performed simultaneously in order to exclude any possible relationship between changes during sampling and storage of the samples, and the variation of the different protein values were quantitated by single radial immunodiffusion from the same sample.

\section{Evaluation of results}

The results were evaluated using standard statistical techniques. The coefficient of variation (CV) is expressed for 1 standard deviation as a percentage of the mean. For the assessment of significant differences between 2 means the Student t-test was used. The correlation coefficient $\mathrm{r}$ was calculated using a computer Olivetti $P 602$ and programs for the covariance matrix without log transformation and for correlation and simple linear regression. The following points have been evaluated:

1. From the results of the precision control the $\mathrm{CV}$ was determined.

2. The 27 "triple" samples were evaluated in the following way:

From each group of the "triple" values the mean was calculated and the single values were expressed as a percentage of the mean, which was $100 \%$. The transformation of the values to a percentage of the mean seemed to be the best way to compare the values from all patients. From the results the CV was calculated.

3. The IgG values were divided into a group of normal levels (10 "triple" values) and a group of elevated levels (17 "triple" values). The data were examined to see whether a significant difference existed between these 2 groups in respect to the deviation of values.

4. The CV of the total protein values from the 81 serum samples was determined after transformation of the values as a percentage of the mcan of the "triple" values. Further, the coefficients of correlation were calculated between the corresponding values of the total protein and each albumin, IgG, IgA and IgM.

\section{Results}

1. Repeated quantitations of the precision control are shown in table 2, from which the range, mean, 1 standard deviation and the CV of the repeated determinations of the aliquoted samples of the pooled normal sera are evident.

2. Deviation of the single determinations of 3 consecutive days from the mean of the "triple" values was expressed as a percentage of the mean. Table 3 shows the range (maximum deviation of all values) and the $\mathrm{CV}$ for the total protein and 4 proteins estimated.

3. Comparison of the deviation of the single values from the mean of the "triple" values between normal

Tab. 2. Repeated quantitations of the quality (precision) control.

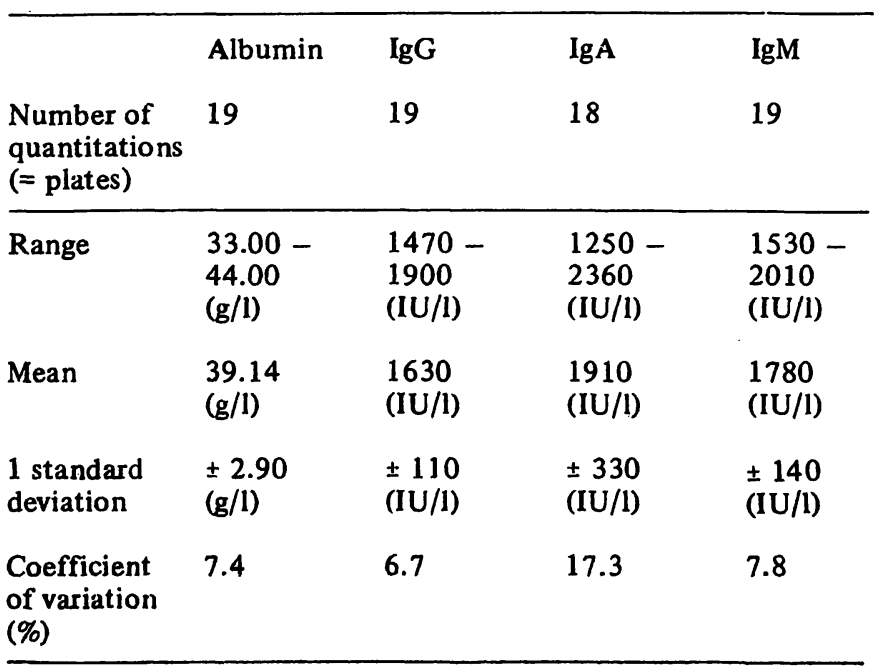

Tab. 1. Application of samples on Partigen immunodiffusion plates bearing 12 circularly arranged wells: a) without, b) with quality (precision) control.
Well nr.

a)

standard dilution 1

standard dilution 2

standard dilution 3

sample day 1

sample day 2

sample day 3

standard dilution 1

standard dilution 2

standard dilution 3

sample day 1

sample day 2

sample day 3 b)

standard dilution 1

standard dilution 3

quality control

sample day 1

sample day 2

sample day 3

standard dilution 2

standard dilution 3

sample day 1

sample day 2

sample day 3 quality control 
Tab. 3. Deviation of the single determinations of 3 consecutive days from the mean of the "triple" values (\% of the mean).

\begin{tabular}{|c|c|c|c|c|c|}
\hline & $\begin{array}{l}\text { Albu- } \\
\min ^{+)}\end{array}$ & $\left.\mathrm{IgG}^{+}\right)$ & $\operatorname{Ig} A^{+)}$ & $\operatorname{IgM}^{+)}$ & $\begin{array}{l}\text { Total pro- } \\
\text { tein }\end{array}$ \\
\hline $\begin{array}{l}\text { Number of } \\
\text { determina- } \\
\text { tions }\end{array}$ & 81 & 81 & 81 & 81 & 81 \\
\hline $\begin{array}{l}\text { Number of } \\
\text { "triple" } \\
\text { samples }\end{array}$ & 27 & 27 & 27 & 27 & 27 \\
\hline $\begin{array}{l}\text { Range (\% of } \\
\text { the mean) }\end{array}$ & $\begin{array}{l}85- \\
116\end{array}$ & $\begin{array}{l}81- \\
120\end{array}$ & $\begin{array}{l}89- \\
111\end{array}$ & $\begin{array}{l}87- \\
115\end{array}$ & $\begin{array}{l}86- \\
110\end{array}$ \\
\hline $\begin{array}{l}\text { Coefficient } \\
\text { of variation } \\
\text { (\%) }\end{array}$ & 5.8 & 7.3 & 4.4 & 5.2 & 3.9 \\
\hline
\end{tabular}

+) Quantitated by single radial immunodiffusion

$++)$ Quantitated by the biuret method

Tab. 4. Comparison of the deviation of the single values from the mean of the "triple" values between normal and elevated IgG values.

\begin{tabular}{|c|c|c|}
\hline & $\begin{array}{l}\text { Elevated values } \\
(>2000 \mathrm{IU} / \mathrm{l})\end{array}$ & $\begin{array}{l}\text { Normal values } \\
(1000-2000 \mathrm{IU} / \mathrm{l})\end{array}$ \\
\hline Number of determinations & 51 & 30 \\
\hline $\begin{array}{l}\text { Number of "triple" } \\
\text { samples }\end{array}$ & 17 & 10 \\
\hline Mean deviation (\%) & \pm 6.0 & \pm 5.0 \\
\hline 1 standard deviation (\%) & \pm 5.3 & \pm 3.5 \\
\hline
\end{tabular}

Tab. 5. Coefficients of correlation ( $\mathrm{r}$ ) and probability levels (p) for the total protein and corresponding values of the 4 proteins.

\begin{tabular}{lll}
\hline $\begin{array}{l}\text { Correlation between } \\
\text { total protein and }\end{array}$ & $\begin{array}{l}\text { Coefficient of } \\
\text { correlation }(\mathrm{r})\end{array}$ & $\begin{array}{l}\text { Probability } \\
\text { level }(\mathrm{p})\end{array}$ \\
\hline Albumin & 0.059 & $>0.1$ \\
IgG & 0.224 & $>0.02>0.05$ \\
IgA & 0.162 & $>0.1$ \\
IgM & 0.158 & $>0.1$ \\
\hline
\end{tabular}

and elevated IgG values. Table 4 shows the mean deviation and the 1 standard deviation of the mean deviation. The difference is statistically non significant $(t=0.581, p>0.1)$.

4. Correlation between the total protein and corresponding values of the 4 proteins. Table 5 shows the coefficient of correlation ( $r$ ) and the probability level (p) for the different correlations.
Tab. 6. Coefficients of variation of protein quantitations by single radial immunodiffusion from previous studies (4).

\begin{tabular}{|c|c|c|c|c|c|}
\hline Variation & $\begin{array}{l}\text { Batch of } \\
\text { plates }\end{array}$ & $\begin{array}{l}\alpha_{1} \text {-Anti- } \\
\text { trypsin }\end{array}$ & IgG & IgA & IgM \\
\hline On one plate & $\begin{array}{l}\mathbf{A} \\
\mathbf{B}\end{array}$ & $\begin{array}{l}3.1 \\
4.4\end{array}$ & $\begin{array}{l}3.0 \\
2.0\end{array}$ & $\begin{array}{l}2.4 \\
3.1\end{array}$ & $\begin{array}{l}3.8 \\
2.3\end{array}$ \\
\hline $\begin{array}{l}\text { Between plates } \\
(n=3)\end{array}$ & $\begin{array}{l}\mathbf{A} \\
\mathbf{B}\end{array}$ & $\begin{array}{l}2.4 \\
8.6\end{array}$ & $\begin{array}{l}2.8 \\
2.8\end{array}$ & $\begin{array}{l}4.3 \\
8.6\end{array}$ & $\begin{array}{l}16.7 \\
23.7\end{array}$ \\
\hline $\begin{array}{l}\text { Between } 20(19) \\
\text { days on plates of } \\
\text { different bat- } \\
\text { ches }(n=1 / \text { day) }\end{array}$ & $\mathbf{A}$ & 6.7 & $(9.3)$ & 7.7 & $(14.6)$ \\
\hline
\end{tabular}

\section{Discussion}

The precision of the single radial immunodiffusion method depends on several critical factors: dilution of standard and serum samples, volume of applied sample, qualities of the agar, such as water content and thickness of the gel, the antigen-antibody relation influenced by the dilution of the sample and the antibody concentration in the agar gel, time and temperature of incubation, transport and storage of commercial plates and finally reading of the precipitation diameters. Furthermore, factors which apply to all methods, e. g. sampling and storage procedures and the individual skill of the technician, may influence the methodical error.

In previous studies (4) we have determined the intrinsic error in the methods of the quantitation by single radial immunodiffusion. Using the same procedure as in the present study, the deviation of values was measured on one plate of the same batch, on different plates of the same batch and on plates of the same batch on different days. It is evident from table 6, that the coefficient of variation (CV) for repeated determinations of the same serum sample on the same plate was below $4 \%$ on average. The $C V$ tended to increase when values of 3 plates of the same batch were pooled and was sig: nificantly higher for IgM. The determinations performed on different days showed higher CV from $7=15 \%$ for all fractions (table 6).

The repeated quantitations of the aliquoted pooled serum (precision control) of this study measuring the samples on different days on plates from different batches gave $\mathrm{CV}$ of around $7 \%$ for albumin, IgG and IgM, but $17.3 \%$ for IgA (table 2). Since the performance of the method in our hands has obviously improved, especially for IgM, even using plates from different batches, the high CV for IgA might reflect a variation in the specificity of different anti-IgA-sera in the plates from different batches reacting differently with the IgA from various individuals in the pooled 
control serum. It is also possible that polymerization of IgA might have influenced the variation.

The present study was part of a clinical study (6) which investigated the influence of an immunosuppressive treatment on different diagnostic parameters in patients with chronic hepatitis. For several reasons it is likely that the findings obtained in these patients are also relevant for normal conditions:

- There were only cases of long-standing disease without acute changes. Alterations of protein concentrations due to the underlying disease are not very likely because no definite trend in the values for a given protein over 3 days was present.

- A large number of the values was within the normal range.

- There was no indication of qualitative changes in the proteins studied.

- Any differences occurring between the variation in normal and abnormal protein levels could be attributed to methodical factors (table 3 ).

Cirrhosis is known to be associated with changes in the metabolism of albumin and immunoglobulins $(7,8,9)$, but no such cases were included in this study.

For the 3 consecutive days on which samples were measured simultaneously on the same plate, the $\mathrm{CV}$ of the obtained values are distinctly higher than the CV due to the intrinsic error in the method, which had been determined previously under the same conditions (see table 6). It could be suspected that the increase in the error was due to changes which influence the water content of the samples. In vivo, hydration and blood distribution which depends on the body position could cause day to day variation, while technical factors such as sampling and storage procedures may also play an important role in determining the water content of the samples. Any factors influencing the protein concentrations by changes of the water content of the samples would very likely cause concordant changes to all proteins measured from the same sample simultaneously. The obvious lack of a distinct correlation between the values of the total protein and the different proteins (table 5) excludes the possibility that these factors are a main cause of the variation. The important in-

\section{References}

1. Mancini, G., Carbonara, A. O. \& Heremans, J. F. (1965), Immunochemistry 2, 235-254.

2. Fahey, J. L. \& McKelvey, E. M. (1965), J. Immunol. 94, 84-90.

3. Asamer, H., Gabl, F. \& Reiner, G. (1967), Wien. Klin. Wochenschr. 79, 853-856.

4. Gabl, F. \& Spath, P. (1969), VII th International Congress of Clinical Chemistry, Genève/Evian, September 8-13, 1969. Abstracts, pp. 341-342, S. Karger, Basel, New York.

5. Richterich, R. (1971), Klinische Chemie, 3. Auflage, pp. 305-309, S. Karger, Basel.

6. Platzer, S., Asamer, H., Födisch, H. J., Gabl, F., Huber, H., fluence of biological fluctuations of individual protein concentrations from one day to the other needs further studies for clarification. However, our results are in agreement with the findings of Allansmith et al. (10), who reported an average variation within $\pm 17 \%$ at 2 standard deviations exceeding the methodical error for human immunoglobulin levels in healthy subjects examined weekly over a period of 25 consecutive weeks.

As is shown for the quantitations of IgG (table 4), elevated values show a slightly higher variation in comparison to values in the normal range, but no statistically significant difference could be assessed. It is in accordance with our experience that higher protein concentrations show a greater deviation of the diameters of the precipitation rings at multiple applications, than lower antigen concentrations.

The maximum deviation from the mean of the individual "triple" determination values, even when measured on the same plate, was as high as $\pm 20 \%$ in some instances. Assuming that 2 standard deviations are sufficient for the significant distinction of 2 values on the same plate, a difference of 9 to $15 \%$ depending on the protein, is necessary. These limits of confidence have to be necessarily higher if the samples are quantitated on different plates at different times by different persons, amounting to a higher methodical error. This is evident from the results of the repeated determinations of the precision control. Thus, it depends on the methodical accuracy how small differences between values can be distinguished with statistical significance. An improvement of the immunodiffusion plates can be achieved by increasing the antibody concentration in the agar allowing the application of larger sample volumes without dilution.

From the findings of this study the important role of several factors for the accuracy of the single radial immunodiffusion method is evident, i. e. for the achievement of reproducible values this method must be performed with great care using an adequate technique. As it is valid for all quantitations on blood samples it should be kept in mind that the total error of a method is also influenced by the sampling and storage procedures (11).

Judmeier, G. \& Spath, P. (1973), Wien. Klin. Wochenschr. $85,509-514$.

7. Waldman, T. A. \& Strober, W. (1969), Progr. Allergy 13, $1-110$.

8. Rothschild, M. A., Oratz, M. \& Schreiber, S. S. (1972), N. Engl. J. Med. 286, 816-821.

9. Vidon, N. \& Bernier, J. J. (1972), Pathol. Biol. 20, 71-81.

10. Allansmith, M., McClellan, B. \& Butterworth, M. (1967), Proc. Soc. Exp. Biol. Med. 125, 404-407.

11. Gabl, F. (1971), Ther. Umschau 28, 658-661.

Prof. Dr. F. Gabl A-1097 Wien

Spitalgasse 23

1. Med. Univ. Klinik 